\title{
Eperjesi Egyetem
}

Cím: Eperjes, November 17. utca 15.

Honlap: https://www.unipo.sk

E-mail: unipo@unipo.sk

Eperjesi Egyetem Egyetemi Könyvtára

Cím: Eperjes, November 17. utca 1.

Honlap: http://www.pulib.sk/web/kniznica/strana/nazov/uvodna-strana

E-mail: library@pulib.sk

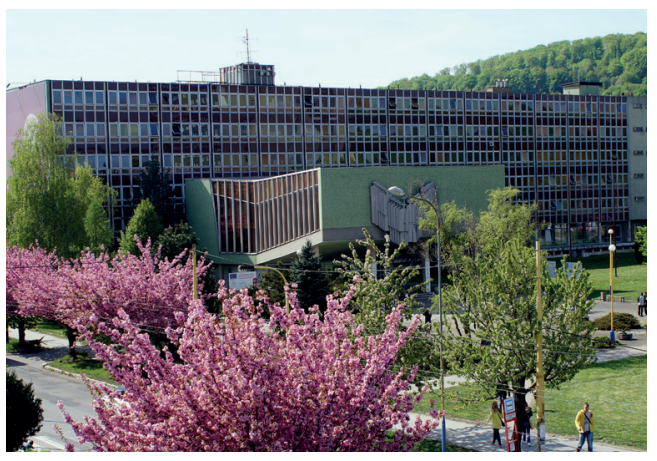

Az Eperjesi Egyetem (Prešovská univerzita v Prešove - PU) 1997. január 1-én alakult meg. Ekkor vált ki a kassai Pavol Jozef Šafárik Egyetemből (Univerzita P.J. Šafárika - UPJŠ), amelynek egészen 1959-től része volt. (Meg kell említeni, hogy Eperjesen már a Šafárik Egyetem megalakulása előtt lehetett főiskolai tanulmányokat végezni.) Saját egyetem megalakulása a helyi lakosok több évszázados igyekezetének eredménye volt, amely egészen az 1667-ben alakult, híres evangélikus kollégium történetéhez vezethető vissza. Jelenleg az Eperjesi Egyetemen több mint 8300 diák tanul hét egyetemi tudományos és pedagógiai intézményben és nyolc karon: Bölcsészettudományi Kar (1959), Görögkatolikus Teológia Kar (1880-1950, megújult 1990-ben), Humán- és Természettudományi Kar (1997), Menedzsment Kar (2004), Pedagógiai Kar (1949), Pravoszláv Hittudományi Kar (1950), Sporttudományi Kar (2004) és Egészségtudományi Kar (2002). Az egyetem több tudományterületen gyakorolja a habilitációs és professzori kinevezési jogokat.

Az Eperjesi Egyetem Egyetemi Könyvtár (Univerzitná knižnica Prešovskej univerzity v Prešove - UK PU) múködését két történelmi könyvtár alapozta meg: az evangélikus kollégium könyvtára és a görögkatolikus püspökségi könyvtár. Az egyetem könyvtára az 1949-ben alakult, amikor Kassán létrehozták a pozsonyi Szlovák Egyetem Pedagógiai Karát és vele együtt a könyvtárat is. 1952. július 8-án a Pedagógiai Kar, és vele

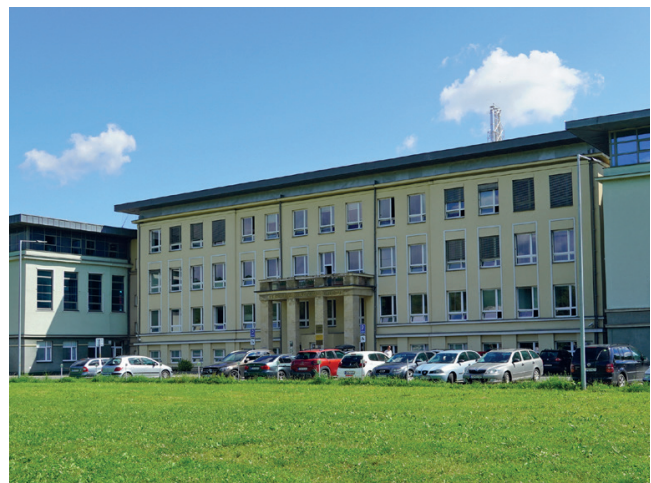


együtt a könyvtár is, Eperjesre lett áthelyezve. 1997-ben, az Eperjesi Egyetem létrehozásával a könyvtár is megkapta mai elnevezését. A gyűjtemény elsősorban az egyetem diákjainak és dolgozóinak biztosít könyvtári és információs szolgáltatásokat. A könyvtárnak egy központi része és két kihelyezett telephelye van, amelyek a kölcsönzési és a tájékoztató szolgáltatásokat biztosítják. Az egyetemi könyvtárnak jelenleg 6060 beiratkozott felhasználója van, akik tanulmányaikhoz és tudományos munkájukhoz 303 férőhelyen 6 kutatóteremben használhatják a gyüjteményt. A könyvtár állománya 220986 kötet, ebből 750 digitális egység. 2019-ben a könyvtár összesen 257451 kölcsönzést tudott lebonyolítani, és ezen felül 51 kulturális és társadalmi eseménynek adott helyet (kiállítás, konferencia, beszélgetés, könyvbemutató stb.). A rendezvényeken 60452 fő vett részt, és a könyvtárnak 355690 internetes látogatója volt.
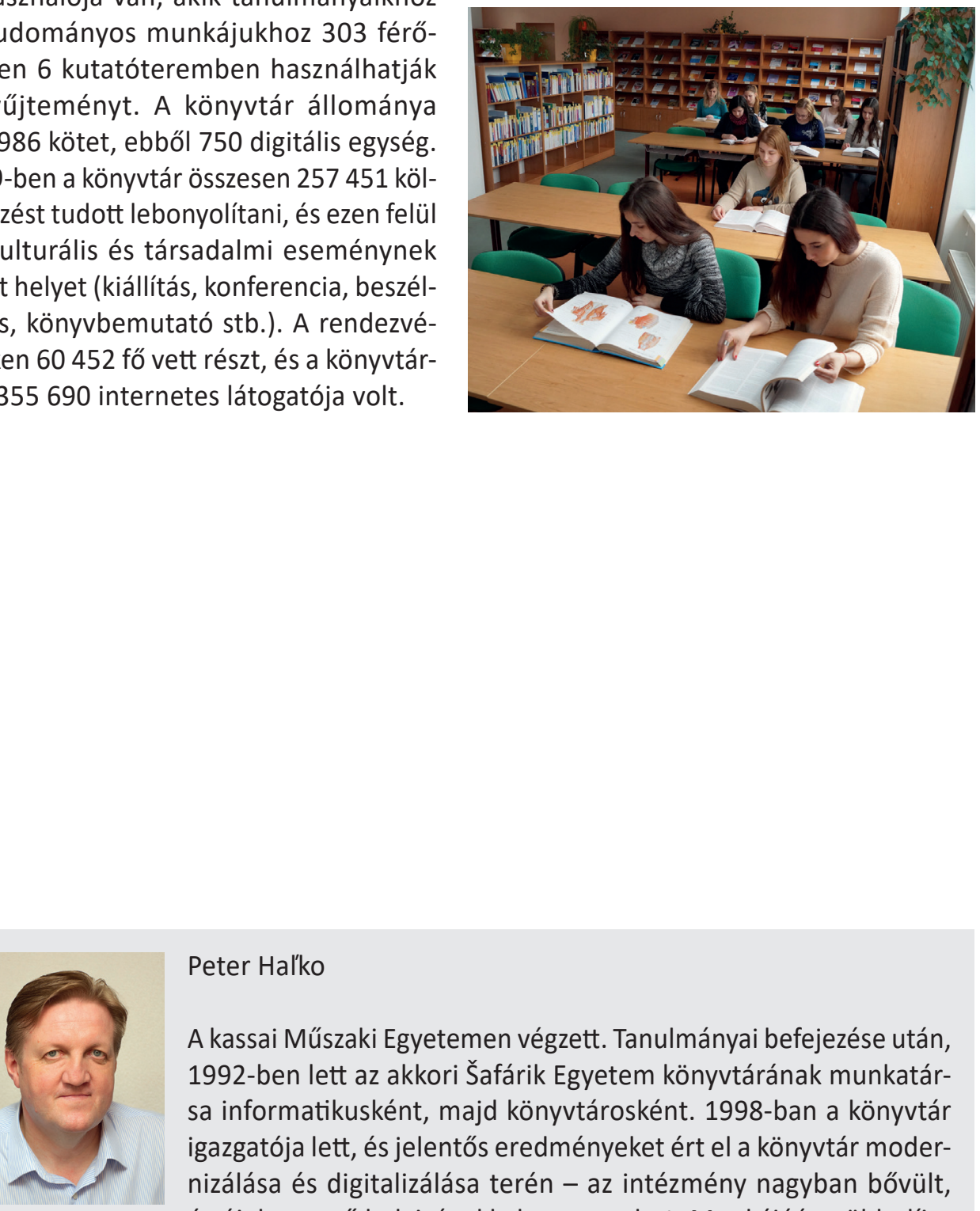

Peter Hal'ko

A kassai Műszaki Egyetemen végzett. Tanulmányai befejezése után, 1992-ben lett az akkori Šafárik Egyetem könyvtárának munkatársa informatikusként, majd könyvtárosként. 1998-ban a könyvtár igazgatója lett, és jelentős eredményeket ért el a könyvtár modernizálása és digitalizálása terén - az intézmény nagyban bővült, és új, korszerü helyiségekkel gyarapodott. Munkájáért több díjat kapott, így 2017-ben az Eperjesi Egyetem Ezüst Medálját. 